\title{
KUALITAS PERAIRAN SUNGAI MUSI BAGIAN TENGAH DAN HILIR SERTA KELIMPAHAN JENIS IKAN
}

\author{
Susilo Adjie ${ }^{1)}$ dan Samuel1) \\ 1) Peneliti pada Balai Riset Perikanan Perairan Umum, Mariana-Palembang \\ Teregristrasi I tanggal: 30 April 2008; Diterima setelah perbaikan tanggal: 21 Oktober 2008; \\ Disetujui terbit tanggal: 31 Oktober 2008
}

\begin{abstract}
ABSTRAK
Penelitian untuk mengetahui kualitas lingkungan perairan Sungai Musi bagian tengah dan hilir serta kelimpahan jenis ikan, telah dilakukan dari bulan April sampai dengan Oktober 2003. Metode penelitian menggunakan metode survei dengan menetapkan 15 stasiun pengamatan dari Sungai Musi bagian tengah sampai dengan hilir. Hasil pengamatan menunjukkan bahwa dari hasil pemeriksaan parameter fisika kimia air secara umum perairan Sungai Musi bagian tengah sampai dengan hilir belum terlihat ada indikasi pencemaran. Kehidupan ikan di Sungai Musi bagian tengah sampai dengan hilir belum terlihat ada gangguan akibat pencemaran air. Jenis-jenis ikan yang dijumpai di sepanjang stasiun pengamatan terdapat sekitar 85 jenis yang didominansi oleh famili Cyprinidae. Penyebaran jenis ikan terkonsentrasi di Sungai Musi bagian tengah \pm 75 jenis dan bagian hilir \pm 58 jenis.
\end{abstract}

KATAKUNCl: $\quad$ kualitas perairan, Sungai Musi bagian tengah dan hilir,kelimpahan jenis ikan

ABSTRACT: Water quality of the middle and lower part of Musi River and its abundance of fish. By: Susilo Adjie and Samuel

A study to determine the water quality in the middle and lower parts of Musi River as well as its fish distribution was conducted from April until October 2003. Research was done under survey method by setting 15 stations in the middle and lower parts of Musi River. Results of the features of the physico chemical parameters showed that Musi River waters in the middle and lower parts were not polluted. There were 85 fish founded in the observed areas and they were dominated by family of cyprinidae. 75 fish species were distributed in the middle part of Musi River and 58 fish species were scattered in the lower.

\section{KEYWORDS: $\quad$ water quality, middle and lower parts of Musi River, fish abundance}

\section{PENDAHULUAN}

Indonesia memiliki potensi sumber daya perairan umum, sungai, dan rawa demikian luas yang tersebar di beberapa pulau terutama di Sumatera, Kalimantan, dan Irian Jaya. Sungai Musi sebagai sungai yang terpanjang dan terluas di Sumatera, ditinjau dari segi perikanan mempunyai peranan yang penting sebagai sumber protein hewani bagi masyarakat, mata pencaharian nelayan, dan lainlain. Pollnac \& Malvestuto (1991) memperkirakan bahwa pencemaran Sungai Musi lebih bobot dibandingkan dengan Sungai Kapuas, demikian pula sumber daya perikanan sudah banyak mendapat tekanan ekologis dari luar terutama pembangunan sektor pertanian dan industri yang berakibat langsung terhadap kehidupan ikan.

Berdasarkan pada ciri-ciri fisik, ketinggian letak, dan jarak, maka Sungai Musi dalam profil memanjang (Iongitudinal profile) dapat dibagi menjadi 3 yaitu wilayah hulu dimulai dari Teberena sampai dengan Muara Kelingi berjarak $\pm 187 \mathrm{~km}$ dengan ketinggian 600 sampai dengan $40 \mathrm{~m}$ di atas permukaan laut (dpl).
Wilayah tengah dimulai dari Muara Kelingi sampai dengan ke Desa Tebing Abang berjarak $\pm 177 \mathrm{~km}$ dengan ketinggian 40 sampai dengan $15 \mathrm{~m}$ dpl. Wilayah bagian hilir dimulai dari Desa Tebing Abang sampai dengan Muara (Selat Bangka) berjarak \pm 146 $\mathrm{km}$ dengan ketinggian antara 15 sampai dengan $0 \mathrm{~m}$ dpl. (Samuel et al., 2003).

Di perairan Musi banyak terdapat industri-industri besar seperti industri pengolahan minyak bumi dan petrokimia pertamina, industri pupuk pusri, industri kayu lapis, industri minyak sawit, pabrik pengolahan karet, $\mathrm{HPH}$, perkebunan, dan lain-lain yang diperkirakan buangan limbah mempunyai dampak negatif terhadap sumber daya ikan. Perairan sungai di bagian tengah terkenal dengan keragaman jenis ikan yang tinggi, namun juga mendapat tekanan ekologis. Di sisi lain, perairan sungai terutama di bagian hilir merupakan daerah pertemuan antara air laut dengan air tawar dan terkenal banyak habitat yang menjadi tempat terjebak nutrien sehingga daerah perairan ini relatif lebih subur (Odum, 1971). Perairan bagian hilir merupakan daerah asuhan benih-benih 
ikan, terutama jenis-jenis ikan yang bermigrasi seperti ikan patin (Pangasius spp.) dan udang galah (Macrobrachium rosenbergii). Perairan ini mempunyai sifat yang agak berbeda dengan bagian hulu dan tengah. Aliran air tidak selalu berjalan ke 1 arah tetapi di bagian ini terjadi fluktuasi pasang surut yang dipengaruhi oleh dinamika pergerakkan air laut di daerah estuaria. Penumpukan bahan pencemaran yang diakibatkan oleh limbah industri sekitar, besar kemungkinan akan terjadi, sehingga kerusakkan habitat hidup ikan mungkin terjadi di wilayah perairan ini. Penelitian ini bertujuan untuk mengetahui tentang kualitas perairan Sungai Musi bagian tengah dan hilir serta kelimpahan jenis ikan sebagai informasi dasar untuk menunjang pengelolaan sumber daya ikan di Sungai Musi.

\section{BAHAN DAN METODE}

Penelitian ini dilaksanakan di perairan Sungai Musi bagian tengah dan hilir dengan menggunakan metode survei dan analisis laboratorium. Pengambilan contoh 4 kali pada bulan April, Juli, September, dan Oktober 2003. Letak stasiun pengamatan ditetapkan 15 lokasi di Sungai Musi bagian tengah dan hilir (Gambar 1).

Parameter kualitas air yang diukur setiap stasiun penelitian meliputi parameter fisika (kecerahan, suhu,
DHL, dan substrat dasar) dan parameter kimia $(\mathrm{pH}$, $\mathrm{DO}, \mathrm{CO}_{2}$ bebas total alkalinitas, kesadahan, kebutuhan oksigen biokimiawi $=\mathrm{BOD}_{5}$ day, $\mathrm{N}-\mathrm{NH}_{3}$, Total $\mathrm{N}$, Total $\mathrm{P}$, dan salinitas) (Tabel 1). Beberapa parameter kualitas air seperti kecerahan, suhu, daya hantar listrik, $\mathrm{pH}, \mathrm{DO}, \mathrm{CO}_{2}$ total alkalinitas, kesadahan, $\mathrm{BOD}_{5}$ day, dan salinitas di ukur langsung di lapangan. Parameter kualitas air lain $\mathrm{N}-\mathrm{NH}_{3}$, Total $\mathrm{N}$ dan Total $\mathrm{P}$ diukur di laboratorium. Pengukuran parameter fisika dan kimia air mengacu pada buku petunjuk APHA (1981); Boyd (1979). Baku mutu air berdasarkan pada PP 82 tahun 2001.

Pengumpulan spesimen ikan diambil dari hasil tangkapan nelayan dengan menggunakan berbagai macam alat tangkap (jaring, jala, cerok, dan pancing). Pengumpulan spesimen ikan dilakukan pada saat survei di lapangan. Kelimpahan jenis ikan ditentukan berdasarkan pada jumlah jenis ikan yang diperoleh nelayan di lapangan. Ikan dicatat nama lokal, tempat tertangkap dan dimasukkan ke dalam kantong plastik yang berisi larutan formalin untuk dibawa ke laboratorium. Ikan diidentifikasi di laboratorium berdasarkan pada kunci identifikasi dari buku Kottelat et al. (1993); Weber \& De Beaufort (1916). 
Kualitas Perairan Sungai Musi Bagian Tengah dan Hilir serta Kelimpahan Jenis Ikan (Adjie, S. \& Samuel)

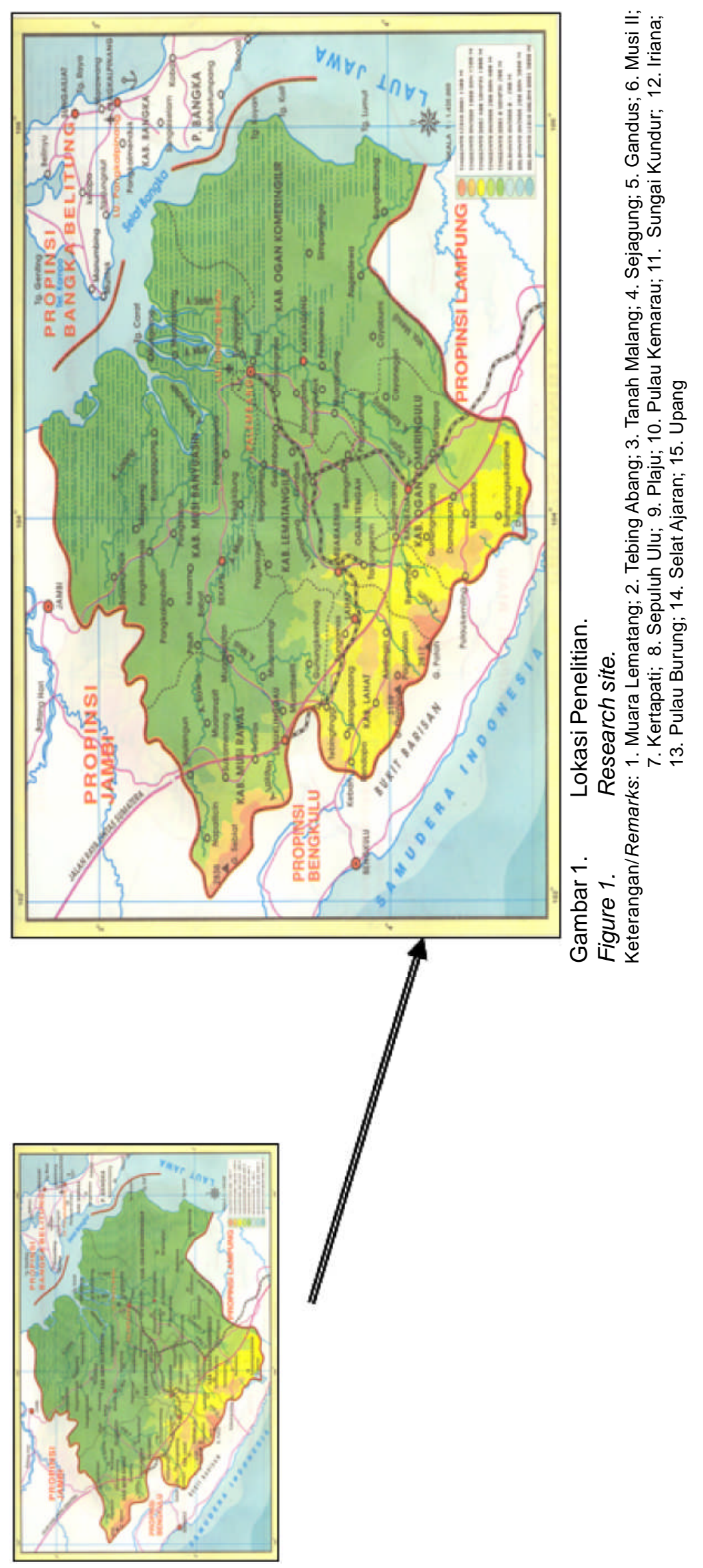


Tabel 1. Parameter fisika kimia yang diukur serta metode atau alat untuk mengukur Table 1. Physico chemical parameters measured and methods for its measurement

\begin{tabular}{|c|c|c|}
\hline No. & Parameter/Parameters & Metode/alat/Method/instrument \\
\hline I & Fisika/Physic & \\
\hline 1. & Kecerahan $(\mathrm{cm})$ & Piring Sechi \\
\hline 2. & Suhu $\left({ }^{\circ} \mathrm{C}\right)$ & Termometer air raksa \\
\hline 3. & $\mathrm{DHL}(\mu \mathrm{S}$ per $\mathrm{cm})$ & SCT-meter \\
\hline 4. & Substrat dasar & Ekman dredge \\
\hline 5. & Salinitas & Refraktometer \\
\hline II & Kimia/Chemist & \\
\hline 1. & $\mathrm{pH}$ (unit) & pH-indikator universal \\
\hline 2. & $\mathrm{DO}(\mathrm{mg}$ per I) & Titrimetrik (Winkler) \\
\hline 3. & $\mathrm{CO}_{2}(\mathrm{mg}$ per I) & Titrimetrik \\
\hline 4. & T-Alkalinitas (mg per I $\left.\mathrm{CaCO}_{3} \mathrm{eq}\right)$ & Titrimetrik \\
\hline 5. & Kesadahan (mg per I $\mathrm{CaCO}_{3} \mathrm{eq}$ ) & Titrimetrik \\
\hline 6. & Kebutuhan oksigen biokimiawi = BOD (mg per I) & Titrimetrik (Winkler), Inkubasi \\
\hline 7. & $\mathrm{~N}-\mathrm{NH}_{3}$ (mg per I) & Spektrofotometer (Phenate) \\
\hline 8. & T-N (mg per I) & Spektrofotometer (Nessler) \\
\hline 9. & $\mathrm{~T}-\mathrm{P}(\mathrm{mg}$ per I) & Spektrofotometer (Vanadate molibdate) \\
\hline
\end{tabular}

\section{HASIL DAN BAHASAN}

\section{Kualitas Perairan Sungai Musi}

Hasil pengukuran parameter kualitas air Sungai Musi selama penelitian (bulan April, Juli, September, dan Oktober 2003) dapat dilihat pada Tabel 2. Suhu air di perairan yang di teliti selama 4 kali pengamatan pada bulan April, Juli, September, dan Oktober 2003 berkisar antara 24 sampai dengan $29^{\circ} \mathrm{C}$. Berdasarkan pada baku mutu kualitas air untuk suhu berkisar antara 20 sampai dengan $32^{\circ} \mathrm{C}$, maka kondisi perairan Musi ditinjau dari parameter suhu cukup baik untuk mendukung kehidupan ikan.

\section{Kecerahan air}

Kecerahan air Sungai Musi yang di teliti berkisar antara 15 sampai dengan $50 \mathrm{~cm}$ (Tabel 2). Kecerahan yang rendah di beberapa tempat akibat ada bahan organik yang berasal dari rawa-rawa yang masuk ke badan sungai atau sedimen tersuspensi sehingga mengakibatkan air sungai keruh. Berdasarkan pada baku mutu kualitas air untuk kecerahan $>45 \mathrm{~cm}$, maka berdasarkan pada kriteria tersebut, kecerahan air di beberapa tempat yang diteliti di perairan Sungai Musi tergolong rendah.

\section{Daya Hantar Listrik}

Boyd (1979) mengatakan bahwa nilai daya hantar listrik perairan alami sekitar 20 sampai dengan 1.500 $\mu \mathrm{S}$ per $\mathrm{cm}$, sedangkan perairan laut dapat memiliki nilai daya hantar listrik yang sangat tinggi, karena banyak garam-garam yang terlarut di dalam. Nilai daya hantar listrik perairan Musi yang di periksa berkisar 39,3 sampai dengan $132,7 \mu \mathrm{S}$ per $\mathrm{cm}$. Nilai daya hantar listrik di stasiun 10 terlihat relatif lebih tinggi, karena di stasiun tersebut terdapat industri karet, diduga limbah industri karet menyebabkan daya hantar listrik tinggi. Menurut baku mutu kualitas air, nilai yang baik untuk daya hantar listrik 150 sampai dengan 500 $\mu S$ per $\mathrm{cm}$. Sebagai perbandingan, nilai daya hantar listrik Sungai Citarum dan anak-anak sungai berkisar antara 20 sampai dengan $320 \mu \mathrm{S}$ per $\mathrm{cm}$ (Kartamihardja et al., 1987) relatif menggolongkan perairan baik bagi kehidupan ikan. Atas dasar tersebut, nilai daya hantar listrik perairan Musi dari wilayah bagian tengah dan hilir menunjukkan nilai yang relatif baik untuk kehidupan ikan.

\section{Derajat Keasaman $(\mathrm{pH})$}

Boyd (1979) mengatakan bahwa perairan dengan pH antara 6,5 sampai dengan 9,0 merupakan kisaran yang paling sesuai untuk memproduksi ikan. Menurut baku mutu kualitas air, ambang batas $\mathrm{pH}$ air untuk keperluan perikanan (Golongan $\mathrm{C}$ ) antara 6 sampai dengan 9. Derajat keasaman $(\mathrm{pH})$ di perairan yang diteliti berkiasar antara 6 sampai dengan 7. Dengan berpedoman pada 3 kriteria tersebut di atas, maka perairan Musi dalam keadaan yang layak untuk mendukung kehidupan ikan dan organisme air lain. 


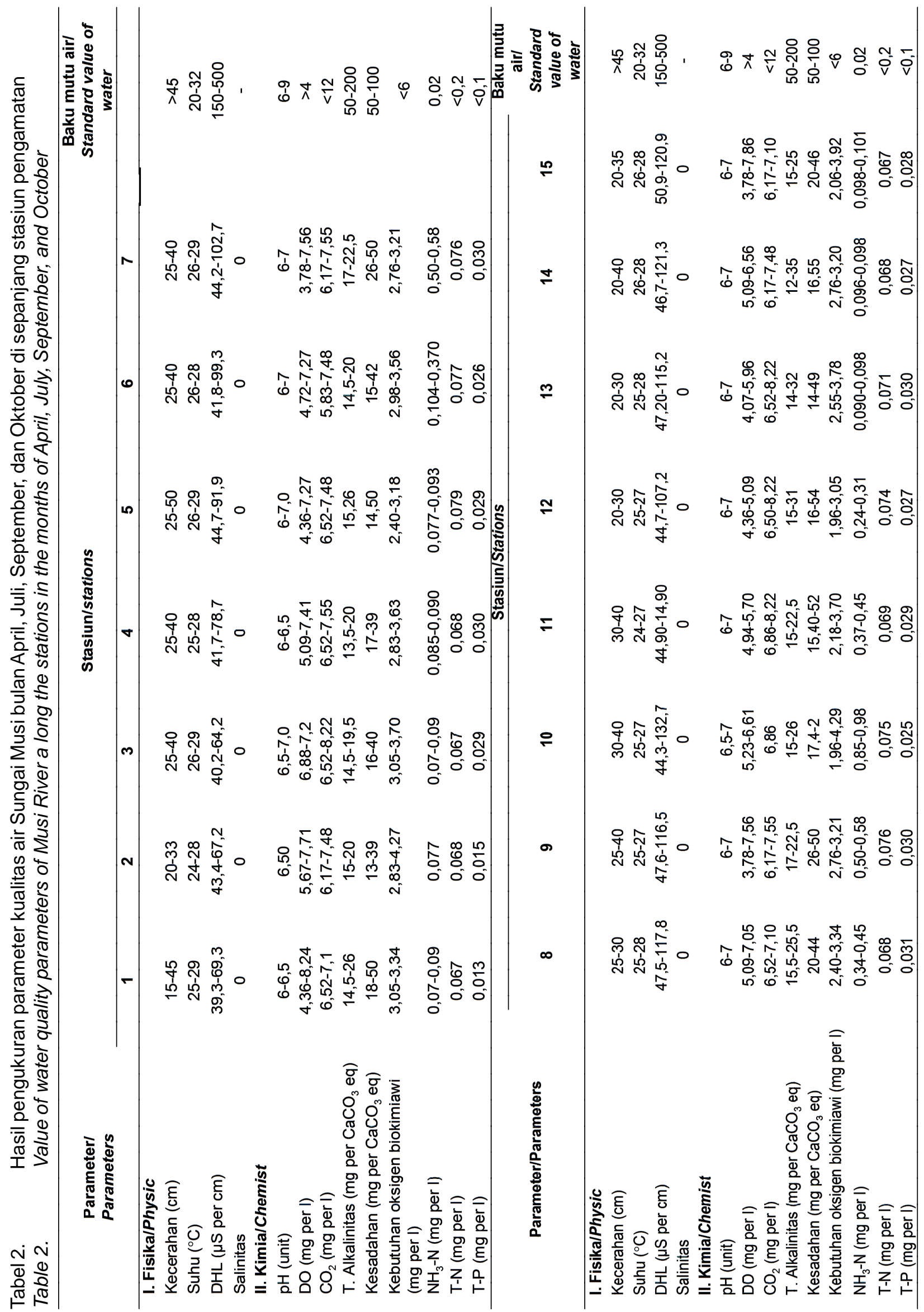




\section{Oksigen $\left(\mathrm{O}_{2}\right)$ Terlarut}

Secara umum, agar kehidupan ikan di perairan dapat layak dan kegiatan perikanan berhasil, maka kandungan oksigen terlarut sebaiknya tidak boleh kurang dari $4 \mathrm{mg} \mathrm{O}_{2}$ per I, hal ini sesuai dengan baku mutu kualitas air untuk perikanan. Hasil pengukuran kandungan oksigen terlarut di wilayah Sungai Musi bagian tengah dan hilir berkisar antara 3,78 sampai dengan 8,24 mg per I. Di stasiun 7, 9, dan 15 nilai oksigen terlihat relatif rendah, karena di stasiun 7 terdapat industri semen dan di stasiun 9 terdapat industri minyak bumi, diduga nilai oksigen rendah di perairan tersebut disebabkan oleh reduksi oksigen dari limbah yang masuk ke perairan tersebut, sedangkan di stasiun 15 sudah dekat dengan muara sungai sehingga sudah terpengaruh dengan air laut, karena kelarutan oksigen dan gas-gas lain juga berkurang dengan meningkat salinitas (Effendi, 2000). Namun demikian, dari nilai oksigen yang terukur menunjukkan bahwa perairan Musi dilihat dari kandungan oksigen layak untuk mendukung kehidupan organisme perairan termasuk kehidupan ikan.

\section{Karbondioksida $\left(\mathrm{CO}_{2}\right)$-Bebas}

Hasil pengukuran kandungan $\mathrm{CO}_{2}$-bebas pada wilayah Sungai Musi bagian tengah dan hilir berkisar antara 6,17 sampai dengan $8,22 \mathrm{mg}$ per I. Menurut baku mutu kualitas air untuk nilai $\mathrm{CO}_{2}$-bebas maksimum $15 \mathrm{mg}$ per l. Nilai kandungan $\mathrm{CO}_{2}$-bebas pada perairan yang diteliti di bawah ambang batas yang membahayakan bagi kehidupan ikan.

\section{Alkalinitas}

Nilai alkalinitas antara 0 sampai dengan $10 \mathrm{mg}$ per I $\mathrm{CaCO}_{3}$ mengindikasikan kualitas air sangat masam, antara 10 sampai dengan $50 \mathrm{mg}$ per $\mathrm{I} \mathrm{CaCO}_{3}$ perairan tergolong kurang produktif, antara 50 sampai dengan $200 \mathrm{mg}$ per I $\mathrm{CaCO}_{3}$ perairan digolongkan mempunyai alkalinitas sedang dan produktivitas perairan juga sedang. Nilai alkalinitas pada perairan alami jarang lebih besar dari $500 \mathrm{mg}$ per $\mathrm{I} \mathrm{CaCO}_{3}$. Nilai alkalinitas yang baik berkisar antara 30 sampai dengan $500 \mathrm{mg}$ per I $\mathrm{CaCO}_{3}$. Nilai alkalinitas pada perairan alami $40 \mathrm{mg}$ per I $\mathrm{CaCO}_{3}$ (Boyd, 1979). Alkalinitas perairan Musi pada perairan yang di periksa berkisar antara 12 sampai dengan $35 \mathrm{mg}$ per $1 \mathrm{CaCO}_{3}$. Rendah nilai alkalinitas tersebut diduga ada hubungan dengan air limbah yang masuk ke badan sungai sewaktu pabrik membuang limbah sehingga air agak bersifat asam. Perairan Musi ditinjau dari nilai alkalinitas mempunyai tingkat kesuburan air yang rendah.

\section{Kesadahan}

Untuk keperluan perikanan nilai kesadahan yang baik menurut baku mutu kualitas air berkisar antara 50 sampai dengan $100 \mathrm{mg}$ per I. Hasil pengukuran nilai kesadahan di perairan Musi bagian tengah dan hilir berkisar antara 13 sampai dengan $55 \mathrm{mg}$ per I $\mathrm{CaCO}_{3}$, termasuk klasifikasi perairan lunak. Air permukaan memiliki nilai kesadahan yang lebih kecil daripada air tanah. Perairan dengan nilai kesadahan kurang dari $120 \mathrm{mg}$ per I $\mathrm{CaCO}_{3}$ dan melebihi $500 \mathrm{mg}$ per I $\mathrm{CaCO}_{3}$ dianggap kurang baik bagi peruntukkan domestik, pertanian, dan industri (Effendi, 2000).

\section{Kebutuhan Oksigen Biokimiawi}

Perairan alami nilai BOD berkisar antara 0,5 sampai dengan $7,0 \mathrm{mg}$ per I, perairan dengan nilai BOD $10 \mathrm{mg}$ per I dianggap telah mengalami pencemaran (Jeffries \& Mills dalam Effendi, 2000). Hasil pengukuran nilai BOD perairan Musi bagian tengah dan hilir berkisar antara 1,96 sampai dengan $4,29 \mathrm{mg}$ per I. Kisaran nilai tersebut menandakan bahwa perairan Musi dari tengah sampai dengan ke hilir belum tercemar limbah organik.

\section{Total Nitrogen (T-N)}

Nitrogen merupakan salah satu unsur penting bagi pertumbuhan fitoplankton dalam membentuk dan memelihara protein nabati yang menjadi rantai pertama dalam siklus rantai makanan di perairan. Hasil pengukuran kandungan total- $\mathrm{N}$ perairan Musi bagian tengah dan hilir berkisar antara 0,067 sampai dengan $0,076 \mathrm{mg}$ per I. Keadaan ini menggolongkan perairan Musi mempunyai kandungan nitrogen di bawah optimum (Canter \& Hill, 1979).

\section{Total Fosfor (T-P)}

Fosfor merupakan unsur esensial bagi tumbuhan tingkat tinggi dan algae, sehingga unsur ini menjadi faktor pembatas bagi tumbuhan dan algae perairan dan sangat mempengaruhi tingkat produktivitas perairan. Klasifikasi perairan berdasarkan pada kadar fosfor total 0 sampai dengan $0,02 \mathrm{mg}$ per I untuk perairan dengan tingkat kesuburan rendah, 0,021 sampai dengan 0,05 $\mathrm{mg}$ per I tingkat kesuburan sedang dan 0,051 sampai dengan 0,1 mg per I tingkat kesuburan tinggi (Effendi, 2000). Hasil pengukuran kadar fosfor total perairan Musi bagian tengah dan hilir berkisar antara 0,013 sampai dengan $0,031 \mathrm{mg}$ per I. Dengan demikian, perairan Musi digolongkan dengan tingkat kesuburan rendah sampai dengan sedang. Wilayah bagian hilir mempunyai kandungan 
total fosfor lebih tinggi dibandingkan dengan wilayah Musi bagian tengah.

\section{Amoniak $\left(\mathrm{NH}_{3}-\mathrm{N}\right)$}

Sumber senyawa nitrogen di sungai terutama berasal dari limbah pertanian, limbah rumah tangga, dan industri (Goldman \& Horne, 1983). Kandungan amoniak tinggi pada air sungai menyebabkan ada pencemaran. Kandungan amoniak Musi bagian tengah dan hilir berkisar antara 0,07 sampai dengan 0,101 $\mathrm{mg}$ per I. Kandungan amoniak agak tinggi $(0,98 \mathrm{mg}$ per I) terdapat di stasiun 10 di mana pada lokasi tersebut terdapat industri pupuk. Namun demikian, di bawah kriteria yang membahayakan bagi kehidupan ikan, karena baku mutu kualitas air untuk amoniak $<1 \mathrm{mg}$ per l.

\section{JENIS DAN KELIMPAHAN IKAN}

Komposisi jenis ikan pada perairan Sungai Musi sepanjang stasiun pengamatan dapat dijumpai sekitar 85 jenis yang didominansi oleh kelompok Cyprinidae (Tabel 3). Sebaran jenis ikan terkonsentrasi pada Sungai Musi bagian tengah \pm 75 jenis, sedangkan di bagian hilir \pm 58 jenis. Wilayah Musi bagian tengah merupakan wilayah yang banyak terdapat jenis ikan. $\mathrm{Hal}$ ini, disebabkan wilayah ini merupakan perairan tipe rawa banjiran di mana banyak terdapat tempat berlindung, tempat memijah, dan meletakkan telur, banyak terdapat makanan bagi ikan sehingga cocok sebagai tempat hidup berbagai jenis ikan air tawar. Kehidupan ikan di Sungai Musi bagian tengah dan hilir sepanjang lokasi pengamatan belum terlihat ada gangguan akibat pencemaran air.

Menurut Samuel et al. (2003) mengatakan bahwa jenis-jenis ikan di perairan Sungai Musi selama penelitian tahun 2002 telah diidentifikasi berjumlah sekitar 86 jenis dari 22 famili dan 3 jenis udang. Jenis ikan yang termasuk dalam famili Cyprinidae merupakan yang terbanyak. Berdasarkan pada daerah penyebaran terkonsentrasi pada wilayah tengah sekitar $85 \%$ diikuti oleh wilayah hilir sekitar $65 \%$ dan wilayah hulu sekitar $23 \%$. Ondara (1992) mengatakan bahwa jenis ikan air tawar asli yang mendominansi perairan tawar Sumatera dan Kalimantan adalah jenis ordo Ostariophysi (Cyprinid dan Siluroid), ordo Labirinthysi (Anabantid dan Ophiocephalid), ordo Percomorphi (famili Nandidae), ordo Opistomi (famili Mastacembelidae), dan ordo Malacopterygii (famili Notopteridae). 
Tabel 3. Jenis-jenis ikan yang teridentifikasi sepanjang stasiun pengamatan di perairan Sungai Musi bagian tengah dan hilir pada bulan April, Juli, September, dan Oktober 2003

Table 3. Fish species identified long the stations in the middle and lower parts of Musi River in the months of April, July, September, and October 2003

\begin{tabular}{|c|c|c|c|c|c|}
\hline \multirow{2}{*}{ No. } & \multirow{2}{*}{$\begin{array}{l}\text { Jenis ikan/ } \\
\text { Fish species }\end{array}$} & \multirow{2}{*}{$\begin{array}{c}\text { Nama IImiah/ } \\
\text { Scientific name }\end{array}$} & \multirow{2}{*}{ Famili/Family } & \multicolumn{2}{|c|}{ Kelimpahan/Abundance } \\
\hline & & & & Tengah/Middle & Hilir/Lower \\
\hline 1. & Aro merah mato & Osteochilus melanopleura & Cyprinidae & + & + \\
\hline 2. & Bawal putih & Pampus orgenteus & Cyprinidae & + & + \\
\hline 3. & Bilis & Rasbora lateristriata & Cyprinidae & - & + \\
\hline 4. & Gegali/Maliki/Kerali & Lobocheilos sp. & Cyprinidae & + & - \\
\hline 5. & Elang & Puntius tetrazona & Cyprinidae & + & + \\
\hline 6. & Haji & Puntius anchisporus & Cyprinidae & + & - \\
\hline 7. & Juar & Luciosoma trinema & Cyprinidae & + & + \\
\hline 8. & Kebarau & Hampala macrolepidota & Cyprinidae & ++ & + \\
\hline 9. & Keperas & Puntius sp. & Cyprinidae & + & + \\
\hline 10. & Kepah & Barbodes sp. & Cyprinidae & + & - \\
\hline 11. & Kepiat & Barbodes sp. & Cyprinidae & + & + \\
\hline 12. & Kerali & Lobocheilos falcifer & Cyprinidae & + & - \\
\hline 13. & Lambak & Labiobarbus ocellatus & Cyprinidae & ++ & - \\
\hline 14. & Lampam & Barbodes schwanefeldii & Cyprinidae & ++ & - \\
\hline 15. & Lemajang & Cyclocheilichthys enoplos & Cyprinidae & + & + \\
\hline 16. & Lumopako & Thynichthys polylepis & Cyprinidae & + & + \\
\hline 17. & Maliki & Lobocheilos sp. & Cyprinidae & + & - \\
\hline 18. & Mentulu & Barbichthys laevis & Cyprinidae & + & - \\
\hline 19. & $\begin{array}{l}\text { Meriko/Puntung } \\
\text { hanyut }\end{array}$ & Balantiocheilos melanopterus & Cyprinidae & + & - \\
\hline 20. & Palau & Osteochilus hasseltii & Cyprinidae & + & + \\
\hline 21. & Selusur batang & Epalzeorhynchus kallopterus & Cyprinidae & + & - \\
\hline 22. & Selimang & Crossocheilus oblongus & Cyprinidae & + & - \\
\hline 23. & Selimang bangkung & Crossocheilus sp. & Cyprinidae & + & - \\
\hline 24. & Semuringan & Puntius fasciatus & Cyprinidae & + & - \\
\hline 25. & Semutih & Lobocheilos bo & Cyprinidae & + & - \\
\hline 26. & Senggiringan & Puntius fasciatus & Cyprinidae & + & - \\
\hline 27. & Siamis & Chela oxygaster & Cyprinidae & + & - \\
\hline 28. & Sihitam & Labeo chryssophekadion & Cyprinidae & + & + \\
\hline 29. & Umbut & Cyclocheilichthys repasson & Cyprinidae & + & - \\
\hline 30. & Ringau & Thynnichthys thynnoides & Cyprinidae & + & + \\
\hline 31. & Coli & Albulichthys albuloides & Cyprinidae & + & + \\
\hline 32. & Baung & Mystus nemurus & Bagridae & ++ & + \\
\hline 33. & Baung Jaksa & Mystus wycki & Bagridae & + & - \\
\hline 34. & $\begin{array}{l}\text { Biji duren/ baung } \\
\text { munti }\end{array}$ & Bagroides melapterus & Bagridae & + & - \\
\hline 35. & Baung buntak & Mystus nemurus & Bagridae & + & + \\
\hline 36. & Berengit & Mystus nigriceps & Bagridae & + & + \\
\hline 37. & Duri & Arius venosus & Bagridae & - & + \\
\hline 38. & Layang-layang & Bagrichthys macracanthuss & Bagridae & + & - \\
\hline 39. & Merundu/Lundu & Mystus gulio & Bagridae & + & + \\
\hline 40. & Tikusan/tiang layar & Bagrichthys hypselopterus & Bagridae & + & - \\
\hline 41. & Juaro & Pangasius polyuranodon & Pangasidae & + & + \\
\hline 42. & Patin & Pangasius djambal & Pangasidae & + & + \\
\hline 43. & Patin Lubuk & Pangasius nasutus & Pangasidae & ++ & + \\
\hline 44. & Riu & Pangasius macronema & Pangasidae & + & - \\
\hline 45. & Timah & Kryptopterus apogon & Siluridae & + & - \\
\hline 46. & Lais & Kryptopterus sp. & Siluridae & + & - \\
\hline 47. & Sengarat & Belodontichthys dinema & Siluridae & + & + \\
\hline
\end{tabular}


Tabel3. Lanjutan

Table 3. Continue

\begin{tabular}{|c|c|c|c|c|c|}
\hline \multirow{2}{*}{ No. } & \multirow{2}{*}{$\begin{array}{l}\text { Jenis ikan/ } \\
\text { Fish species }\end{array}$} & \multirow{2}{*}{$\begin{array}{c}\text { Nama IImiah/ } \\
\text { Scientific name }\end{array}$} & \multirow{2}{*}{ Famili/Family } & \multicolumn{2}{|c|}{ Kelimpahan/Abundance } \\
\hline & & & & ngah/Middle & Hilir/Lower \\
\hline 48. & Tapa & Wallago leerii & Siluridae & + & + \\
\hline 49. & Betok & Anabas testudineus & Anabantidae & + & + \\
\hline 50. & Gurame & Osphronemus goramy & Anabantidae & + & + \\
\hline 51. & Petek & Ctenops vittatus & Anabantidae & - & + \\
\hline 52. & Bujuk & Channa melanopterus & Channidae & + & + \\
\hline 53. & Gabus & Channa striata & Channidae & ++ & - \\
\hline 54. & Sepengkah & Ambassis gymnocephalus & Channidae & + & - \\
\hline 55. & Toman & Channa microleptes & Channidae & ++ & - \\
\hline 56. & Sepat siam & Trycogaster pectoralis & Belontiidae & ++ & + \\
\hline 57. & Sepat merah mato & Tricogaster tricopterus & Belontiidae & ++ & + \\
\hline 58. & Botia & Botia macracanthus & Cobitidae & + & - \\
\hline 59. & Langli & Botia hymenophysa & Cobitidae & + & - \\
\hline 60. & Lidah & Cynoglossus sp. & Cynoglossidae & + & + \\
\hline 61. & Sebelah & Cynoglossus sp. & Cynoglossidae & + & ++ \\
\hline 62. & Pirang & Setipinna melanochir & Engraulididae & + & - \\
\hline 63. & Parang-parang & Coilia lindmani & Engraulididae & + & + \\
\hline 64. & Sapil/Tembakang & Helostoma teminckii & Helostomatidae & ++ & + \\
\hline 65. & Piluk & Macrognathus aculeatus & Mastacembelidae & + & - \\
\hline 66. & Tilan & Mastacembelus unicolor & Mastacembelidae & + & - \\
\hline 67. & Belida & Chitala lopis & Notopteridae & + & + \\
\hline 68. & Putak & Notopterus notopterus & Notopteridae & + & + \\
\hline 69. & Kepor/Sepatung & Pristolepis fasciata & Pristolepididae & + & + \\
\hline 70. & Gulamo & Sciaena russelti & Sciaenidae & + & + \\
\hline 71. & Udang abang & Metapenaeus monoceros & Sergestidae & + & ++ \\
\hline 72. & Udang pipih & Metapenaeus brevicornis & Sergestidae & - & + \\
\hline 73. & Lais timah & Cryptopterus schilbeides & Biluridae & + & + \\
\hline 74. & Keli & Clarias meladerma & Clariidae & + & + \\
\hline 75. & Buntal laut & Diodon hystrix & Diodontidae & - & + \\
\hline 76. & Julung-julung & Zenarchopterus sp. & Hemirhamphidae & + & + \\
\hline
\end{tabular}

Keterangan/Remarks: - = tidak ditemukan (absent); + = sedikit $($ few $) ;++=$ sedang $($ medium) $;+++=$ banyak (abundance)

\section{KESIMPULAN}

Beberapa perairan di Sungai Musi bagian tengah sampai dengan hilir yang kondisi perairan cukup baik ditemukan sekitar 82 jenis ikan yang didominansi oleh kelompok Cyprinidae. Penyebaran jenis ikan terkonsentrasi pada Sungai Musi bagian tengah yakni \pm 75 jenis, sedangkan di bagian hilir terdapat \pm 50 jenis.

\section{PERSANTUNAN}

Kegiatan dari hasil riset karakteristik habitat dan jenis biota di perairan Musi bagian tengah dan hilir, T. A. 2003, di Balai Riset Perikanan Perairan Umum, Mariana-Palembang.

\section{DAFTAR PUSTAKA}

APHA. 1981. Standard method for the examination of water and wastewater. $15^{\text {th }}$ Edition. APHA inc. Washington D. C. 1134 pp.

Boyd, C. E. 1979. Water quality in warmwater fishponds. Auburn University. Departement of Fisheries and Alied Aquaculture. First Edition. Alabama. USA. 359 pp.

Canter, L. W. \& L. G. Hill. 1979. Handbook of variables environmental assessment. Ann Arbor Science Publishers. Inc. Michigan. 203 pp. 
Effendi, H. 2000. Telaahan kualitas air bagi pengelolaan sumber daya dan lingkungan perairan. Fakultas Perikanan dan IImu Kelautan. Institut Pertanian Bogor. Bogor. 259 pp.

Goldman, C. R. \& A. J. Horne. 1983. Limnology. Mc. Graw Hill inc. Book Comp. London. 464 pp.

Kottelat, M., J. A. Whitten, N. Kartikasari, \& S. Wiryoatmojo. 1993. Freshwater fishes of western Indonesia and Sulawesi. Periplus Edition and EMDI Project Indonesia. Jakarta. 221 pp.

Kartamihardja, E. S., A. S. Nastiti, Krismono, K. Purnomo, \& A. Hardjamulia. 1987. Penelitian limno biologi Waduk Saguling pada tahap pra inundasi. Buletin Penelitian Perikanan Darat. Bogor. 6 (3). 32-62.

Odum, E. P. 1971. Fundamentals of ecology. Third Edition. W. B. Sounders Company. Toronto. 574 pp.
Ondara. 1992. Pemanfaatan dan pengelolaan perikanan perairan lebak lebung. Prosiding Temu Karya IImiah Perikanan Perairan Umum. Pusat Penelitian dan Pengembangan Perikanan. Jakarta. $P$ (89-105).

Pollnac, R. B \& S. P. Malvestuto. 1991. Biological and basic economic condition for the development of riverince fisheries resource in Kapuas and Musi River. 150 pp.

Samuel, S. Adjie \& Subagdja. 2003 Inventarisasi dan distribusi biota serta karakteristik habitat perairan Sungai Musi. Prosiding Hasi-Hasil Riset. Jakarta. 4-5 Pebruari 2003. Pusat Riset Perikanan Tangkap. Jakarta. 20 pp.

Weber, M. \& De Beaufort. 1916. The fishes of the Indo-Australian Archipelago. E. J. Brill Ltd. Leiden. I-XII. 